\title{
Membaca Artikel Akademik Fadhilaturrahmi
}

\section{Adib Rifqi Setiawan}

Pondok Pesantren Ath-Thullab, Madrasah Tasywiquth Thullab Salafiyyah (TBS) Kudus

Jl. KH. Turaichan Adjhuri, Kajeksan, 002/002, Kabupaten Kudus, 59314, Indonesia

alobatnic@gmail.com

\begin{abstract}
Abstrak
Riset ini bertujuan untuk membaca artikel akademik Fadhilaturrahmi sebagai salah satu penulis asal Indonesia. Pendekatan yang dipilih ialah kualitatif kategori deskriptif dengan desain fenomenologi. Data riset dikumpulkan menggunakan teknik pengamatan naturalistic, analisis konten, serta wawancara sosok kunci. Pemeriksaan keabsahan, keandalan, dan keobjektifan data yang diperoleh dilakukan menggunakan teknik triangulasi dan external audit.
\end{abstract}

Kata-kata Kunci: Fadhilaturrahmi; Jurnal Akademik; Riset Pendidikan;

\section{A. Pendahuluan}

Romaḍōn buat saya adalah bulan persiapan. Kalau diumpamakan dengan klub sepak bola, Romaḍōn merupakan ajang pra-musim. Kebetulan saya lahir pada 13 Syawwāl 1414 H. / 26 Maret 1994 M., bulan yang jatuh tepat setelah Romaḍōn. Kalau diselaraskan dengan alur kelahiran, Romaḍon laiknya masa persiapan ketika saya akan dilahirkan. Kebetulan lain ialah saya dididik oleh tradisi pondok pesantren terutama sejak nyantri muqīm di Ma'hadul 'Ulumisy Syar'iyyah Yanbu'ul Qur'an (MUS-YQ). Salah satu tradisi pondok pesantren untuk mengisi bulan Romaḍōn ialah melakukan kajian kitab kuning tertentu yang tidak dipelajari dalam jadwal rutin, seringkali utuh yakni sampai khotam, sekaligus melakukan amalan tertentu secara konsisten, misalnya tadarrus al-Qur'ān dan șolat sunnah. Tradisi tersebut senantiasa saya lestarikan, meski sejak kuliah strata satu di Pendidikan Fisika Universitas Pendidikan Indonesia (UPI) terdapat perubahan dalam bentuk penambahan berupa membaca textbook atau terbitan akademik tertentu.

Dalam Romaḍōn 1441 H./2020 M. ini salah satu fokus saya ialah membaca jurnal akademik karya individu Fadhilaturrahmi, yang kebetulan dilahirkan pada 13 Romaḍon 1402 H. / 5 Juli 1982 M. Beliau merupakan dosen Program Studi S1 PGSD (Pendidikan Guru Sekolah Dasar) Universitas Pahlawan Tuanku Tambusai, Bangkinang, Kabupaten Kampar, Riau (Universitas Pahlawan Tuanku Tambusai, 2019). Riwayat pendidikan tinggi beliau ialah: S1 Pendidikan Kimia (2000-5), S2 Pendidikan Dasar (2009-11), serta S3 Pendidikan Dasar (2013-7), yang semuanya diperoleh dari Universitas Pendidikan Indonesia (UPI), Isola, Sukasari, Kota Bandung, Jawa Barat (Universitas Pahlawan Tuanku Tambusai, 2019).

Fadhilaturrahmi termasuk dosen yang aktif menulis dan terlibat dalam penerbitan akademik. Keaktifan dalam menulis telah membuahkan 16 jurnal akademik sampai sekarang, rinciannya: 8 sebagai penulis tunggal, 5 sebagai co-author dengan Rizki Ananda, serta 3 lainnya berkolaborasi masing-masing dengan Surani Oktavia \& Lusi Marleni, Yuni Astuti \& Rini Parmila Yanti, serta Mimi Rahmi Rosneli \& Adityawarman Hidayat (Google Scholar, 2017). Dalam penerbitan beliau turut menjadi editor di Jurnal Basicedu, Edukatif, Jurnal Cakrawala Pendas, Jurnal Review Pendidikan dan Pengajaran, Elementary, dan Jurnal Abdidas serta sebagai reviewer untuk Jurnal Bola, Jurnal Pendidikan Tambusai, serta Jurnal Cendekia (Setiawan, 2020). 
Jejak digital tersebut membuat perempuan kelahiran Bandung pada 5 juli 1982 ini termasuk dalam sosok yang memiliki komitmen yang tinggi pada profesi dan masyarakat karena melakukan pendidikan, penelitian, dan pengabdian masyarakat yang integral (Mart, 2011; Abdullah, 2010). Jejak digital juga menunjukkan bahwa jurnal akademik Fadhilaturrahmi telah dikutip oleh 81 karya tulis lain, yang membuatnya memiliki Hirsch-index ( $h$-index) sebesar 6 di Google Scholar dan 2 di Scopus seperti direkam oleh SINTA Indonesia (SINTA, 2017; Google Scholar, 2017; Hirsch, 2005). Sementara berdasarkan profil di Google Scholar, beliau memiliki Kardashian index sebesar 0.023 (kalau dikaitkan akun Twitter @ fadhilaturrahmi) bahkan 0 (kalau dikaitkan akun Twitter @ fadhilah_za_) (Google Scholar, 2017; Hall, 2014; Twitter, 2012; 2012). Ini berarti Fadhilaturrahmi termasuk dalam akademisi yang bagus, tapi kurang diperhatikan oleh masyarakat umum.

Tak dimungkiri bahwa jejak digital tersebut juga berpotensi membuat Fadhilaturrahmi mungkin kurang diapresiasi karena dianggap hanya "tingkat nasional" serta kurang bergaung di "tingkat global". Malah kalau ditelisik, seolah jurnal akademik yang diterbitkan oleh penulis merupakan curahan hati tentang kegiatan yang dilakukan dan pengalaman yang diperoleh dalam keseharian sebagai dosen. Namun, Terry Mart menyarankan bahwa cara pasti untuk mengukur kualitas karya tulis dan mengerti kontribusi ilmiahnya ialah dengan membacanya - tidak berdasarkan penerbit tertentu maupun berpijak kepada bibliometrik walau keduanya memang perlu diperhatikan (Mart, 2006). Buat saya pribadi, riset yang dilakukan oleh Fadhilaturrahmi sudah tepat, karena tidak keluar dari tujuan untuk mengerti, mengatasi, dan mengantisipasi masalah maupun mengembangkan potensi-bukan untuk publikasi dan konferensi.

Artikel akademik, seperti jurnal akademik dan makalah konferensi, memiliki tantangan lebih dibanding bahan bacaan lain, misalnya buku pelajaran (textbook). Secara umum, buku pelajaran ditulis untuk pelajar dan artikel akademik ditulis untuk pakar. Akibatnya, buku pelajaran sering memberikan banyak panduan bagi pembaca dengan mengeksploitasi struktur teks dan cara untuk menyoroti informasi penting. Sedangkan artikel akademik kerap mengandung istilah teknis yang tidak populer disertai struktur teks eksplanasi dan argumentatif yang ditulis tanpa mempertimbangkan pembaca umum. Gaya penulisan juga dapat menginspirasi gaya membaca. Misalnya, buku pelajaran yang mengungkapkan konten sebagai beragam fakta bisa menginspirasi pendekatan hafalan terhadap konten, seiring pembaca menganggap keperluan membaca ialah mengingat rincian paragraf yang ditulis dengan laras. Sebaliknya, artikel akademik mengandung argumen persuasif dengan data dan referensi untuk meyakinkan pembaca tentang beberapa klaim.

Aspek tantangan dalam membaca artikel akademik ialah karena terdapat perjuangan untuk mengidentifikasi dan mengerti komponen kunci dari artikel akademik. Dalam perjuangan ini kadang dijumpai kesulitan untuk memahami motivasi dari tuturan serta struktur argumen yang disajikan. Dua aspek yang patut disorot ketika membaca artikel akademik ialah pembaca harus dapat:

1. menemukan dan mengidentifikasi informasi konseptual penting yang diungkap oleh penulis secara tersurat atau tersirat. Ini berguna bagi pembaca untuk dapat membedakan tujuan penulis dari pengantar riset.

2. memahami kaitan antar gagasan penting, baik dalam konteks artikel yang dibaca (secara internal) maupun dalam konteks terbitan akademik (secara eksternal). Ini berguna bagi pembaca untuk mengidentifikasi pertanyaan riset yang disusun, alasan penggunakan desain riset untuk menjawab pertanyaan itu, keselarasan data yang diperoleh dengan pertanyaan dan desain, serta hubungan ketiganya dengan simpulan. 
Berdasarkan sebaran informasi tersebut, riset ini bertujuan untuk membaca artikel akademik Fadhilaturrahmi sebagai salah satu penulis asal Indonesia. Ruang lingkup uraian mencakup 8 jurnal akademik yang telah diterbitkan dalam periode 18 April 2017 - 22 April 2020. Hasil pembacaan tersebut kemudian dibahas lebih lanjut guna menemukan makna karya Fadhilaturrahmi dalam kajian pendidikan. Karena itu, pertanyaan riset ini ialah, "Bagaimana makna karya Fadhilaturrahmi dalam kajian pendidikan berdasarkan jurnal akademik yang telah diterbitkan dalam periode 18 April 2017 - 22 April 2020?”

\section{B. Metode}

Data yang dibutuhkan dalam riset ini ialah 8 jurnal akademik yang telah diterbitkan oleh Fadhilaturrahmi dalam periode 18 April 2017 - 22 April 2020. Berdasarkan tujuan riset dan kebutuhan data, pendekatan yang dipilih ialah kualitatif kategori deskriptif dengan desain fenomenologi (Fraenkel, Wallen, \& Hyun, 2012, hal. 432). Kemudahan metode ini ialah tidak diperlukan tindakan untuk mengutak-atik fenomena. Sedangkan kesulitannya ialah mengutamakan gambaran utuh dari fenomena. Dari penuturan kemudahan dan kesulitan, metode ini dipilih karena kami bermaksud memahami secara menyeluruh fenomena dalam riset ini berupa 8 jurnal akademik yang telah diterbitkan oleh Fadhilaturrahmi dalam periode 18 April 2017 - 22 April 2020.

Data riset dikumpulkan menggunakan teknik pengamatan naturalistic, analisis konten, serta wawancara sosok kunci (Fraenkel, Wallen, \& Hyun, 2012, hal. 446; 453; 478-9). Pengamatan dilakukan secara naturalistic karena kami tidak terlibat dalam penulisan, penelaahan, penyuntingan, serta penerbitkan semua jurnal akademik tersebut. Analisis konten dilakukan terhadap keselarasan jurnal akademik yang diterbitkan dengan dokumen yang diajukan oleh Fadhilaturrahmi untuk mendukung pencalonan gelar akademik berupa skripsi, tesis, dan disertasi serta profesi yang dialami saat ini sebagai dosen. Guna memperkaya data, kami juga melakukan wawancara sosok kunci kepada Fadhilaturrahmi untuk memperoleh informasi lain yang dapat dipakai dalam riset ini.

Pemeriksaan keabsahan, keandalan, dan keobjektifan data yang diperoleh dilakukan menggunakan teknik triangulasi dan external audit (Fraenkel, Wallen, \& Hyun, 2012, hal. 458). Karena itu data yang diperoleh tidak langsung digunakan, melainkan dinilai lebih dulu oleh kami maupun orang lain untuk didapat data yang absah, andal, dan objektif.

\section{Hasil}

Tabel 1 berikut ini menunjukkan 8 jurnal akademik yang telah diterbitkan oleh Fadhilaturrahmi secara individu dalam periode 18 April 2017 - 22 April 2020. Secara keseluruhan, fokus kedelapan jurnal tersebut ialah pendidikan.

Tabel 1. Jurnal Akademik Fadhilaturrahmi dalam periode 18 April 2017 - 22 April 2020

\begin{tabular}{|c|l|l|}
\hline Nomor & Tanggal & Judul \\
\hline$[1]$ & $\begin{array}{l}18 \text { April } \\
2017\end{array}$ & $\begin{array}{l}\text { Peningkatan Hasil Belajar Siswa pada Materi Jaring-Jaring Balok dan } \\
\text { Kubus dengan Pendekatan Contextual Teaching And Learning (CTL) } \\
\text { Siswa Kelas IV SDN 05 Air Tawar Barat (Fadhilaturrahmi, 2017) }\end{array}$ \\
\hline$[2]$ & $\begin{array}{l}01 \mathrm{Mei} \\
2017\end{array}$ & $\begin{array}{l}\text { Penerapan Metode Mind Mapping Untuk Meningkatkan Hasil } \\
\text { Belajar Mahasiswa Semester IIA PGSD Matakuliah Pendidikan } \\
\text { Matematika SD Kelas Rendah (Fadhilaturrahmi, 2017) }\end{array}$ \\
\hline
\end{tabular}




\begin{tabular}{|c|l|l|}
\hline$[3]$ & $\begin{array}{l}\text { 02 Juli } \\
2017\end{array}$ & $\begin{array}{l}\text { Penerapan Pendekatan Saintifik untuk Meningkatkan Kemampuan } \\
\text { Komunikasi Matematik Peserta Didik di Sekolah Dasar } \\
\text { (Fadhilaturrahmi, 2017) }\end{array}$ \\
\hline$[4]$ & $\begin{array}{l}\text { 03 Oktober } \\
2017\end{array}$ & $\begin{array}{l}\text { Pengaruh Pendekatan Open-Ended dan Pendekatan Scientifik } \\
\text { Terhadap Kemampuan Koneksi Matematik Siswa Sekolah Dasar } \\
\text { (Fadhilaturrahmi, 2017) }\end{array}$ \\
\hline$[5]$ & $\begin{array}{l}17 \text { Oktober } \\
2017\end{array}$ & $\begin{array}{l}\text { Lingkungan Belajar Efektif Bagi Siswa Sekolah Dasar } \\
\text { (Fadhilaturrahmi, 2017) }\end{array}$ \\
\hline$[6]$ & $\begin{array}{l}21 \text { April } \\
2018\end{array}$ & $\begin{array}{l}\text { Pengaruh Pembelajaran Kooperatif Tipe STAD dan GI Terhadap } \\
\text { Peningkatan Kemampuan Koneksi Matematik Sekolah Dasar } \\
\text { (Fadhilaturrahmi, 2018) }\end{array}$ \\
\hline$[7]$ & $\begin{array}{l}\text { 04 April } \\
2019\end{array}$ & $\begin{array}{l}\text { Pengaruh Pembelajaran Kooperatif Tipe Gi terhadap Peningkatan } \\
\text { Kemampuan Koneksi Matematik Siswa Sekolah Dasar } \\
\text { (Fadhilaturrahmi, 2019) }\end{array}$ \\
\hline$[8]$ & $\begin{array}{l}22 \text { April } \\
2020\end{array}$ & $\begin{array}{l}\text { Pelatihan Pembelajaran E-Learning Berbasis Edmodo Bagi Guru } \\
\text { Sekolah Dasar (Fadhilaturrahmi, 2020) }\end{array}$ \\
\hline
\end{tabular}

\section{Pembahasan}

Fadhilaturrahmi memperoleh gelar Magister Pendidikan (M.Pd.) Program Studi Pendidikan Dasar dari Universitas Pendidikan Indonesia (UPI). Tesis yang diajukan ialah Pengaruh Pembelajaran Kooperatif Tipe STAD dan GI Terhadap Peningkatan Kemampuan Koneksi dan Komunikasi Matematik Siswa Sekolah Dasar (Fadhilaturrahmi, 2014). Dalam penyelesaian tesis tersebut, Fadhilaturrahmi dibimbing oleh Wahyudin (pada waktu itu sudah dilantik sebagai guru besar) dan Turmudi (pada waktu itu belum dilantik sebagai guru besar). Kedua pembimbing tersebut sama-sama memiliki kepakaran di bidang pendidikan matematika. Dari sini tampak bahwa Fadhilaturrahmi lebih tertarik dengan matematika ketika kuliah S2 Pendidikan Dasar, meski latar belakang S1 beliau ialah Pendidikan Kimia. Ketertarikan tersebut juga tampak oleh 6 dari 8 jurnal akademik yang ditunjukkan dalam tabel 1. terkait dengan pembelajaran matematika. Terdapat 4 kata kunci yang terdapat dalam tesis Fadhilaturrahmi, yakni kemampuan koneksi matematik (competencies of connection mathematics), kemampuan komunikasi matematik (competencies of communication mathematics), pembelajaran kooperatif tipe STAD (cooperative learning type STAD), dan pembelajaran kooperatif tipe GI (cooperative learning type GI). Keempat kata kunci tersebut kelak akan dijumpai dalam beberapa jurnal akademik yang diterbitkan oleh beliau.

\section{[1] Peningkatan Hasil Belajar Siswa pada Materi Jaring-Jaring Balok dan Kubus dengan Pendekatan Contextual Teaching And Learning (CTL) Siswa Kelas IV SDN 05 Air Tawar Barat}

Dalam jurnal Peningkatan Hasil Belajar Siswa pada Materi Jaring-Jaring Balok dan Kubus dengan Pendekatan Contextual Teaching And Learning (CTL) Siswa Kelas IV SDN 05 Air Tawar Barat, Fadhilaturrahmi (2017) menyajikan riset tentang penerapan pendekatan Contextual Teaching and Learning (CTL) dalam pembelajaran matematika topik bangun ruang 3 dimensi. CTL adalah suatu pendekatan pembelajaran yang menekankan kepada proses keterlibatan siswa secara penuh yang memfasilitasi murid untuk bekerja dan mengalami sendiri topik yang dipelajari dengan cara menyajikan informasi fakta ketika pembelajaran di dalam kelas (Fadhilaturrahmi, 2017, hal. 2-3). Tujuan penerapan CTL menurut Fadhilaturrahmi (2017) ialah mendorong murid untuk menghubungkan pengetahuan yang dimilikinya dan menerapkannya dalam kehidupan. 
Tampak kentara bahwa CTL didasarkan kepada teori konstruktivis yang mengapresiasi pemahaman dan pengetahuan murid yang diperoleh dari pengalaman mereka sendiri sebelum memasuki sekolah (Nola \& Irzik, 2006, hal. 175). Fadhilaturrahmi (2017) sendiri menggunakan CTL sebagai cara mengatasi masalah berupa kesulitan murid dalam menentukan jaring-jaring balok dan kubus selain sesuai contoh dari guru. Penyebab kesulitan ini menurut beliau antara lain kekurangan pemodelan dalam pembelajaran seiring guru hanya memberikan soal dari buku pelajaran tanpa mengaitkan dengan keseharian murid (Fadhilaturrahmi, 2017, hal. 2). Hasil yang diperoleh secara umum melalui 7 tahap penerapan CTL selama 2 siklus selalu meningkat di setiap aspek.

Tabel 2. Hasil penerapan CTL oleh Fadhilaturrahmi (2017)

\begin{tabular}{|c|c|c|c|c|c|c|}
\hline \multirow{2}{*}{ Siklus } & \multirow{2}{*}{ Pembelajaran } & \multicolumn{2}{|c|}{ Pelaksanaan } & \multicolumn{3}{c|}{ Aspek (dalam \%) } \\
\cline { 2 - 7 } & & Guru & Murid & Kognitif & Afektif & Psikomotor \\
\hline \multirow{2}{*}{ I } & 1 & 76,92 & 69,23 & 53,12 & 71,00 & 69,23 \\
\cline { 2 - 7 } & 2 & 88,46 & 80,76 & 56,25 & 78,00 & 78,29 \\
\hline \multirow{2}{*}{ II } & 1 & 96,15 & 98,00 & 90,62 & 82,50 & 81,40 \\
\cline { 2 - 7 } & 2 & 96,15 & 98,07 & 93,75 & 90,00 & 86,70 \\
\hline
\end{tabular}

Sayang dalam menyajikan hasil tersebut Fadhilaturrahmi (2017) sepenuhnya menyajikan secara deskriptif tanpa disertai tabel dan grafik untuk meringkas data. Dalam menyajikan secara deskriptif, Fadhilaturrahmi (2017) memiliki kepiawaian tersendiri ketika menuturkan. Sehingga tuturan yang disampaikan terasa mengalir laiknya menyimak beliau bercerita secara lisan. Penyajian deskriptif memang sesuai metode riset yang dipakai beliau, tapi ketiadaan tabel dan grafik menyulitkan saya sebagai pembaca dalam mengidentifikasi klaim bahwa terjadi peningkatan dari sisi proses dan hasil. Malah ketika diringkas dalam tabel 2 tersebut, dapat dilakukan pembahasan lanjut berupa kaitan antar data berdasarkan korelasi Pearson $r$ (reversion) seperti yang pernah saya lakukan dalam Pembelajaran Tematik Berorientasi Literasi Saintifik (Setiawan, 2020, hal. 55; Pearson, 1895, hal. 241; Galton, 1877, hal. 532). Perhitungan korelasi Pearson $r$ yang saya lakukan menunjukkan bahwa pelaksanaan guru dan murid memiliki korelasi positif sebesar 0.979. Lebih lanjut, kaitan antar aspek juga memiliki korelasi positif dengan nilai berikut:

Tabel 3. Kaitan antar aspek hasil penerapan CTL oleh Fadhilaturrahmi (2017)

\begin{tabular}{|c|c|c|c|}
\hline Aspek & Kognitif & Afektif & Psikomotor \\
\hline Kognitif & 1,000 & & \\
\hline Afektif & 0,892 & 1,000 & \\
\hline Psikomotor & 0,855 & 0,985 & 1,000 \\
\hline
\end{tabular}

Riset tentang penerapan CTL dalam pembelajaran matematika topik kubus dan balok memang bukan sesuatu yang baru. Sebelum Fadhilaturrahmi (2017), terdapat riset serupa dengan perbedaan terletak partisipan riset, seperti dilakukan oleh Nova Indah Sari (2013), Sri Hidayah (2014), dan Nita Yulinda (2016), yang secara umum mengarah kepada simpulan bahwa penerapan CTL dapat meningkatkan hasil belajar. Lebih lanjut, Nita Yulinda (2016) juga membahas kaitan antar aspek berupa kemampuan pemecahan masalah matematis dengan kepercayaan diri murid yang keduanya berkorelasi positif sebesar 0,268. Andai Fadhilaturrahmi (2017) melakukan pembahasan seperti itu Nita Yulinda (2016) untuk aspek kognitif, afektif, dan psikomor, beliau memiliki kapling penting berupa data empiris terkait tiga aspek pembelajaran tersebut dari partisipan pelajar Indonesia. Nilai penting ini muncul karena berdasarkan Taksonomi Bloom tujuan pendidikan diklasifikasikan ke dalam aspek 
kognitif, afektif, dan psikomor (Krathwohl, A Revision of Bloom's Taxonomy: An Overview, 2002; Simpson, 1966; Krathwohl, Bloom, \& Masia, 1956; Bloom, Engelhart, Furst, Hill, \& Krathwohl, 1956). Walau sudah lebih dari setengah abad dipakai dalam praktik dan riset pendidikan, data empiri untuk kaitan antar aspek berdasarkan Taksonomi Bloom belum banyak tersedia. Namun tak perlu dipersoalkan, yang jelas Fadhilaturrahmi (2017) menunjukkan bahwa dirinya melakukan riset untuk mengatasi masalah yang ditemui.

Buat saya pribadi, pendekatan CTL di topik ini terbilang andalan sebagai pemancing motivasi belajar siswa Madrasah Ibtidaiyah (MI). Ini terjadi karena murid yang saya hadapi berlatar Islam serta kadang kurang apresiatif kepada matematika. Bangun balok dan kubus sendiri merupakan bentuk umum bak mandi, yang menjadi tempat penampung air. Air termasuk pembahasan fiqh terkait bersuci (tohāroh). Untuk pembelajaran fiqh berbasis kitab kuning atau textbook klasik di MI NU Tasywiquth Thullab Salafiyyah (TBS) Kudus (Setiawan, 2019), pembahasan tersebut terkait dengan tuturan dalam buku Safinat al-Najā berikut:

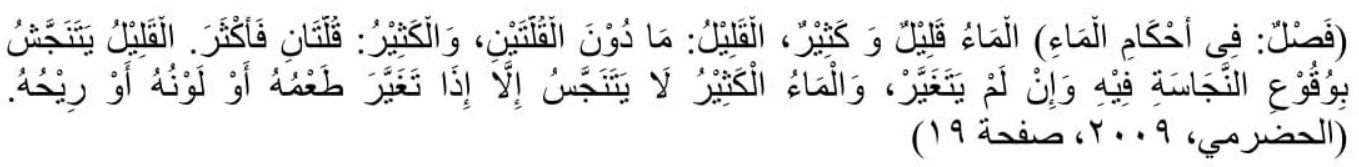

Artinya:

"(Pasal: tentang h̆ukm air) Air ada dua macam: sedikit dan banyak. Air yang sedikit adalah air yang kurang dari dua qullah. Air yang banyak adalah air yang tepat dua qullah atau lebih. Air yang sedikit bisa menjadi najs sebab tercampur najs ke dalamnya, meskipun tidak berubah sama sekali. Air yang banyak tidak bisa menjadi najs, kecuali air tersebut telah berubah rasa, warna, atau baunya."

Kata kunci dalam tuturan tersebut ialah dua qullat (Arab: الْقَتَنَيْنِ). Qullat merupakan ukuran volume yang tidak termasuk dalam satuan internasional (SI). Dua qullat sendiri untuk dalam textbook klasik fiqh, kerap diukur berdasarkan satuan pound (Arab: رِطُ (ر), yang notabene satuan imperial untuk massa, bukan volume (United States National Bureau of Standards, 1959).

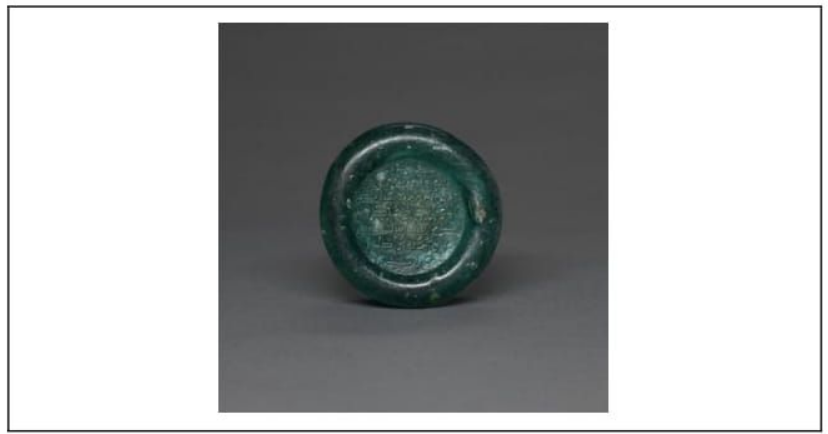

Gambar 1. Warisan Dinasti Umayyah tahun 743 yang menjelaskan ukuran satu pound (Arab: رِطُ) (Walters Art Museum, 2014)

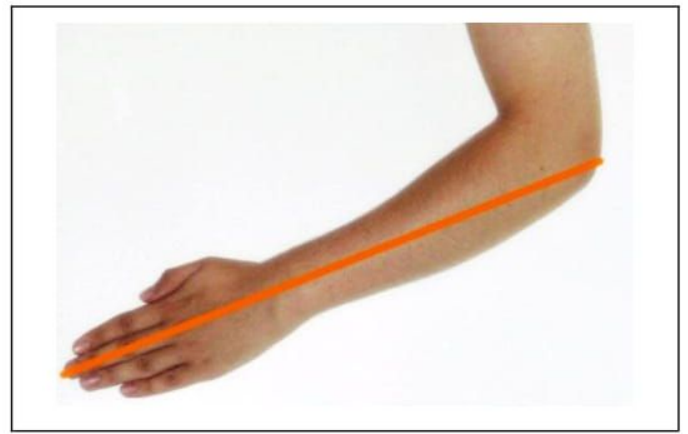

Gambar 2. Ukuran panjang satu hasta

Karena itu, textbook klasik fiqh juga menyajikan konversi ukuran berdasarkan pound ke dalam satuan terkait volume, yakni hasta (Arab: ذَرَاعُ) yang juga tidak termasuk dalam SI. Misalnya dikaitkan dengan bangun kubus yang disampaikan dalam buku Kāsyifat al-Sajā:

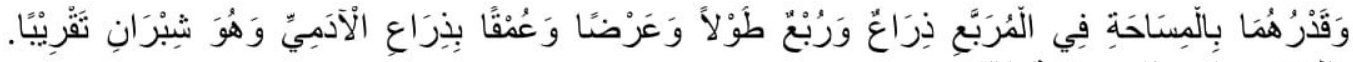

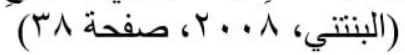



Artinya:
"Ukuran dua qullah berdasarkan luas dalam bangun bentuk bujur sangkar yaitu panjang, lebar, dan dalamnya sebesar satu seperempat hasta manusia, kira-kira dua jengkal tangan.

Dengan demikian, pembelajaran aktual di setiap tingkat dan lembaga Yayasan Tasywiquth Thullab Salafiyyah (TBS) Kudus untuk saat ini kerap disertai penjelasan hasil konversi ukuran dua qullah ke dalam SI, yakni sebanyak 216 liter menurut pendapat jumhūr 'ulamā'.

Kaitan dengan CTL ialah topik air bisa menjadi informasi fakta yang dapat disajikan guna melatih murid menerapkan hasil belajar dari topik kubus dan balok dalam kehidupan. Contoh penyajian bisa dengan menyajikan masalah seperti berikut:

Bak mandi di rumah Fadhilaturrahmi berbentuk balok berukuran panjang 100 $\mathrm{m}$, tinggi $60 \mathrm{~cm}$, dan lebar $40 \mathrm{~cm}$. Ketika baru terisi setengah, najis jatuh ke dalam bak mandi tersebut, tanpa mengubah warna, bau, dan rasa air dalam bak mandi. Fadhilaturrahmi ingat bahwa air dalam bak mandi tidak menjadi mutanajjis, selama najis yang menyampurinya tidak mengubah warna, bau, dan rasanya serta volume air minimal 2 qullah.

Pertanyaan:

1. Bagaimana gambar ilustrasi bak mandi di rumah Fadhilaturrahmi?

2. Bagaimana gambar skema jaring-jaring bak mandi tersebut?

3. Apakah dapat disimpulkan air dalam bak mandi tersebut menjadi mutanajjis?

4. Mengapa dapat disimpulkan seperti itu?

Gambar 3. Contoh lembar kegiatan untuk topik bangun ruang 3 dimensi dalam konteks fiqh

Berdasarkan pembacaan Peningkatan Hasil Belajar Siswa pada Materi Jaring-Jaring Balok dan Kubus dengan Pendekatan Contextual Teaching And Learning (CTL) Siswa Kelas IV SDN 05 Air Tawar Barat karya Fadhilaturrahmi (2017) dan rekaman pembelajaran yang saya alami, tampak bahwa jurnal akademik tersebut dapat dilanjutkan kembali. Kelanjutan tersebut ialah dengan menyusun lembar kegiatan dalam konteks fiqh, yang setelah diterapkan dapat memberi data guna membahas kaitan aspek kognitif, afektif, dan psikomor. Kelanjutan ini tentu tidak dapat dilakukan dalam waktu singkat. Perlu proses panjang mulai menyusun indikator sebagai dasar lembar kegiatan sesuai CTL dalam konteks fiqh yang memuat aspek kognitif, afektif, dan psikomotor, melaksanakan dalam pembelajaran-yang rigid kalau mengikuti kalender pembelajaran SD/MI tapi flexible jika dilakukan di pondok pesantren, serta membahas data yang diperoleh. Namun proses panjang tersebut bukan berarti mustahil dilakukan bukan?

Bersambung...

K.Sb.Po.090941.020520.02:40 


\section{Ucapan Terima Kasih}

Adib Rifqi Setiawan menghaturkan rasa terima kasih kepada Ibu Fadhilaturrahmi, M.Pd. dari Universitas Pahlawan Tuanku Tambusai berkat inspirasi dan motivasi dalam riset ini.

\section{Referensi}

Abdullah, M. (2010, Maret 3). Riset/Publikasi/Paten: Bukan Sekedar Dana, tetapi Juga Komitmen. Dipetik Mei 1, 2020, dari Mari Menjadi Lebih Baik: http://youmikra.blogspot.com/2010/03/risetpublikasipaten-bukan-sekedar-dana.html

Bloom, B. S., Engelhart, M. D., Furst, E. J., Hill, W. H., \& Krathwohl, D. R. (1956). Taxonomy of Educational Objectives: The Classification of Educational Goals. Handbook I: Cognitive Domain. New York City: David McKay Company.

Fadhilaturrahmi. (2014). Pengaruh Pembelajaran Kooperatif Tipe STAD dan GI Terhadap Peningkatan Kemampuan Koneksi dan Komunikasi Matematik Siswa Sekolah Dasar. (W. \&. Turmudi, Penyunt.) Bandung: Universitas Pendidikan Indonesia.

Fadhilaturrahmi. (2017, Oktober 17). Lingkungan Belajar Efektif Bagi Siswa Sekolah Dasar. Jurnal Basicedu, 1(2), 76-84.

Fadhilaturrahmi. (2017, Mei 1). Penerapan Metode Mind Mapping Untuk Meningkatkan Hasil Belajar Mahasiswa Semester IIA PGSD Matakuliah Pendidikan Matematika SD Kelas Rendah. Cendekia : Jurnal Pendidikan Matematika, 1(1), 112-121.

Fadhilaturrahmi. (2017, Juli 2). Penerapan Pendekatan Saintifik untuk Meningkatkan Kemampuan Komunikasi Matematik Peserta Didik di Sekolah Dasar. EduHumaniora : Jurnal Pendidikan Dasar, 9(2), 109-118.

Fadhilaturrahmi. (2017, Oktober 2). Pengaruh Pendekatan Open-Ended dan Pendekatan Scientifik Terhadap Kemampuan Koneksi Matematik Siswa Sekolah Dasar. Mimbar Sekolah Dasar, 4(2), 117-127.

Fadhilaturrahmi. (2017, April 18). Peningkatan Hasil Belajar Siswa pada Materi Jaring-Jaring Balok dan Kubus dengan Pendekatan Contextual Teaching And Learning (CTL) Siswa Kelas IV SDN 05 Air Tawar Barat. Jurnal Basicedu, 1(1), 1-9.

Fadhilaturrahmi. (2018, April 21). Pengaruh Pembelajaran Kooperatif Tipe STAD dan GI Terhadap Peningkatan Kemampuan Koneksi Matematik Sekolah Dasar. Jurnal Basicedu, 2(1), 160165.

Fadhilaturrahmi. (2019, April 4). Pengaruh Pembelajaran Kooperatif Tipe Gi terhadap Peningkatan Kemampuan Koneksi Matematik Siswa Sekolah Dasar. Edukatif :Jurnal Ilmu Pendidikan, $1(1), 43-55$.

Fadhilaturrahmi. (2020, April 22). Pelatihan Pembelajaran E-Learning Berbasis Edmodo Bagi Guru Sekolah Dasar. Jurnal Abdidas, 1(1), 1-6.

Fraenkel, J. R., Wallen, N. E., \& Hyun, H. H. (2012). How to Design and Evaluate Research in Education (8th ed.) (8th ed.). (S. Kiefer, Penyunt.) New York City: McGraw-Hil.

Galton, F. (1877, April 19). Typical Laws of Heredity. Nature, 15(390), 532-533.

Google Scholar. (2017, Mei 9). Fadhilaturrahmi Fadhilaturrahmi - Pengutipan Google Scholar. Dipetik Mei 1, 2020, dari Google Scholar: https://scholar.google.co.id/citations?user=uze1GUAAAAJ\&hl=id

Hall, N. (2014, Juli 30). The Kardashian index: a measure of discrepant social media profile for scientists. Genome Biology, 15, 424.

Hidayah, S. (2014). Peningkatan Hasil Belajar Matematika Materi Jaring-Jaring Kubus dan Balok dengan Model Contextual Teaching and Learning Kelas IV SD Semester 2 di SD 1 Gamong. Kabupaten Kudus: Universitas Muria Kudus (UMK).

Hirsch, J. E. (2005, November 7). An index to quantify an individual's scientific research output. Proceedings of the National Academy of Sciences of the United States of America, 102(46), 16569-16572. 
Krathwohl, D. R. (2002). A Revision of Bloom's Taxonomy: An Overview. Theory Into Practice, 41(4), 212-218.

Krathwohl, D. R., Bloom, B. S., \& Masia, B. B. (1956). Taxonomy of Educational Objectives: The Classification of Educational Goals. Handbook II: Affective Domain. New York City: David McKay Company.

Mart, T. (2006, Februari 1). Counting Papers. Symmetry Magazine, 3(1), hal. 8-9.

Mart, T. (2011, Juli 29). Pembusukan Akademis. Kompas.

Nola, R., \& Irzik, G. (2006). Philosophy, Science, Education and Culture. Berlin, Germany: Springer Science \& Business Media.

Pearson, K. (1895, Juni 20). Note on Regression and Inheritance in the Case of Two Parents. Proceedings of the Royal Society of London, 58, 240-242.

Sari, N. I. (2013). Peningkatan Hasil Belajar Jaring-Jaring Kubus dan Balok dengan Pendekatan Contextual Teaching And Learning (CTL) di Kelas IV SD Angkasa II Lanud Padang. Padang: Universitas Negeri Padang (UNP).

Setiawan, A. R. (2019). Kurikulum Lokal Madrasah Tasywiquth Thullab Salafiyyah (TBS) Kudus. MI NU TBS Kudus. Kudus: Madrasah Tasywiquth Thullab Salafiyyah (TBS) Kudus.

Setiawan, A. R. (2020, April 27). Fadhilaturrahmi. Dipetik Mei 1, 2020, dari ALOBAТИIว: https://alobatnic.blogspot.com/2020/04/fadhilaturrahmi.html

Setiawan, A. R. (2020, Januari 24). Pembelajaran Tematik Berorientasi Literasi Saintifik. (Fadhilaturrahmi, Penyunt.) Jurnal Basicedu, 4(1), 51- 69.

Simpson, E. (1966). The Classification of Educational Objectives in the Psychomotor Domain. Urbana: University of Illinois at.

SINTA. (2017). Fadhilaturrahmi - SINTA - Science and Technology Index. Dipetik Mei 1, 2020, dari SINTA - Science and Technology Index: http://sintadev.ristekdikti.go.id/authors/detail?id=5978277\&view=overview

Twitter. (2012, Februari).Fadhilaturrahmi ZA (@Fadhilah_ZA_) - Twitter. Dipetik Mei 1, 2020, dari Twitter: https://twitter.com/fadhilah_za_

Twitter. (2012, Maret).Fadhilaturrahmi ZA (@Fadhilah_ZA_)|Twitter. Dipetik Mei 1, 2020, dari Twitter: http://twitter.com/fadhilaturrahmi

United States National Bureau of Standards. (1959). Notices "Refinement of values for the yard and the pound". Gaithersburg: United States National Bureau of Standards.

Universitas Pahlawan Tuanku Tambusai. (2019, April 13). Fadhilaturrahmi, S.Pd, M.PdUniversitas Pahlawan Tuanku Tambusai. Dipetik Mei 1, 2020, dari https://universitaspahlawan.ac.id/id/fadhilaturrahmi-s-pd-m-pd/: https://universitaspahlawan.ac.id/id/fadhilaturrahmi-s-pd-m-pd/

Universitas Pahlawan Tuanku Tambusai. (2019, April 13). Program Studi S1 PGSD - Universitas Pahlawan Tuanku Tambusai. Dipetik Mei 1, 2020, dari Universitas Pahlawan Tuanku Tambusai: https://universitaspahlawan.ac.id/id/program-studi-s1-pgsd/

Walters Art Museum. (2014, April 18). Inscribed Pound Weight. Dipetik Mei 1, 2020, dari Walters Art Museum: https://art.thewalters.org/detail/11026

Yulinda, N. (2016). Pengaruh Pendekatan Contextual Teaching and Learning (Ctl) Terhadap Kemampuan Pemecahan Masalah Matematis dan Kepercayaan Diri Siswa Pada Materi Volume Kubus dan Balok (Penelitian Eksperimen Terhadap Siswa Kelas V SDN Palasah dan SDN Mandalaherang I di Ke. Bandung: Universitas Pendidikan Indonesia (UPI).

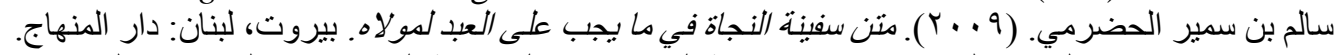

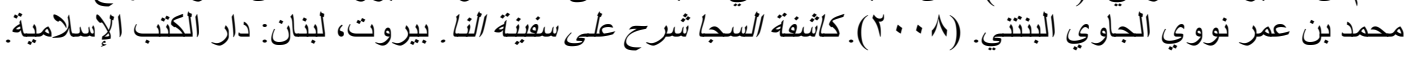

